Available online at GSC Online Press Directory

GSC Biological and Pharmaceutical Sciences

e-ISSN: 2581-3250, CODEN (USA): GBPSC2

Journal homepage: https://www.gsconlinepress.com/journals/gscbps

(RESEARCH ARTICLE)

\title{
Altitudinal and temporal variation of surface water quality: An assessment in Badulu Oya Catchment, Sri Lanka
}

\author{
Rajapaksha R.M.G.N. ${ }^{1}{ }^{*}$, Dharmagunawardhane H.A. ${ }^{1}$, Attanayake A.M.A.N.B. ${ }^{2}$ and Rekha Nianthi K.W.G. ${ }^{3}$ \\ ${ }^{1}$ Postgraduate Institute of Science, University of Peradeniya, Peradeniya, Sri Lanka. \\ ${ }^{2}$ Faculty of Applied Sciences, Uva Wellassa University, Badulla, Sri Lanka. \\ ${ }^{3}$ Department of Geography, University of Peradeniya, Peradeniya, Sri Lanka.
}

Publication history: Received on 13 June 2020; revised on 27 June 2020; accepted on 29 June 2020

Article DOI: https://doi.org/10.30574/gscbps.2020.11.3.0181

\begin{abstract}
Rivers are one of the main surface water resources representing a geographical unit that fulfills wide array of economic and ecological values. Quality of river water is vital for health of river ecosystem and maintain its functions. Climate and altitude are 2 of the main natural factors that influence on quality of the river waters. The study assessed altitudinal and temporal variation of surface water quality in the Badulu Oya catchment. The main river of the catchment was categorized into 3 segments based on altitudinal gradient. Ten physicochemical parameters of stream water were monitored at 14 sampling locations along these segments every other month for 18-month period following standard analysis methods. Results revealed that the observed water quality parameters are significantly varying $(<0.05)$ both seasonally and altitudinally. Results of General Linear Model (GLM) revealed that the electrical conductivity (EC), total dissolved solids (TDS), turbidity, sulphate, nitrate, phosphate and biochemical oxygen demand (BOD) significantly vary $(<0.05)$ seasonally. Further, temperature, dissolved oxygen (DO), sulphate, turbidity, TDS and EC were significantly different $(<0.05)$ between the three river segments. During dry season highest average BOD, pH and phosphate were recorded in the midstream segment indicating possible high urban waste discharges. In the upstream segment, seasonal cultivations and excessive agrochemical usage in sloping lands appear to cause recorded highest EC, TDS, turbidity, and sulphate levels of upstream water. Except for a few sampling locations where BOD and turbidity were higher, all other monitored water quality parameters fall within the guideline ranges of ambient water quality.
\end{abstract}

Keywords: Altitude; Temporal Variation; Surface Water Quality

\section{Introduction}

Surface water is a precious renewable earth resource of which the quality is decisive in many environmental processes and human livelihood and health. Surface water is the most vulnerable resource that is often subjected to diverse threats posed naturally and anthropogenically. Understanding the impacts on surface water quality is important to manage the health of water resource for safe and sustainable use. On the other hand, surface water is the main drinking and other domestic water commodity. Topography, climate, elevation, land use, vegetation, geology and human activities are some important factors that influence the surface water quality [1, 2]. Streams interacting with soils and rocks change the existing quality of the surface waters by leaching and dissolving different minerals. Elevations and hence the gradient of stream decide the flow path, the flow rate and the rate of erosion. Land use determines mostly the contaminants in the stream water while climate is important for the quantity and rate of flow in the stream. These natural factors play an important role in the river liveness and health of it.

River courses can be divided into three segments as upper, middle and lower segments where total energy of a river depends on the river's, gradient and speed [3]. Usually the gradient of the upper segments is steep and possesses large

\footnotetext{
${ }^{*}$ Corresponding author: Rajapaksha R.M.G.N.
} 
amount of gravitational potential and kinetic energy. The upper segments tend mostly to erode the bed vertically whereas middle and lower segments erode the banks laterally. As the river morphological characters change, those differences influence the physicochemical quality of water as well determine the bio diversity of the river.

The rate of runoff and soil characters play an important role allowing seepage and enriching ground water storage and supporting base flow. Altered catchment hydrology and land use can influence the changes in stream water quality especially adding inorganic and organic compounds from the surroundings [4]. Altitude and land slope are important to further stimulate the process.

Several studies on various climatological, hydrological and geological aspects of Badulu Oya have been done during past few decades $[5,6,7,8]$. However, a detailed study integrating all these attributes at the entire catchment scale is lacking. This study aims to analysis of the altitudinal and temporal variation of the surface water quality of Badulu Oya as a part of a wider study on the impacts of climatic and altitudinal changes on surface water bodies.

\section{Material and methods}

\subsection{Study area}

Central highlands of Sri Lanka are imperative to the island since it initiate all major rivers of the country and store and gradually release the rain water by way of these natural river system. Badulu Oya, one of the right bank tributary of river Mahaweli, the longest river of the country originates from the Namunukula Hills, an eastward mountain range belonging to the Central Highlands. Its catchment is considered as one of the highly vulnerable eco systems in the Central Highlands due to extensive cultivation, farming and land degradation that it is undergoing for over two centuries. From its origin to confluence the Badulu Oya traverses approximately $59 \mathrm{~km}$ starting from 1,500 m elevation to the confluence at $100 \mathrm{~m}$ elevation above mean sea level (Fig.1). The river is fed by different feeder channels that flow through diverse topographies, land use patterns, climate zones adding diverse nature to the quality of the its flowing water. The annual mean stream flow is $12 \mathrm{~m}^{3} / \mathrm{s}$ [5] of the catchment. The entire catchment covers $404 \mathrm{~km}^{2}$ bearing pristine habitats for endemic biota as well furnishing domestic water requirements including potable water for urban and rural dwellers. Entire catchment belongs to intermediate zone and different agro climatic conditions prevail in the area that belong to the catchment viz; IU3a, IU3e, IM1a and IL2. Majority of the catchment experiences relatively dry period since its location is in the leeward side of the Central Highlands. However, North East Monsoon brings heavy rain to the catchment and South West Monsoon period is usually dry. Annual average rainfall varies from 900 to $2500 \mathrm{~mm}$ and the annual average temperature varies from $16^{\circ} \mathrm{C}$ to $30^{\circ} \mathrm{C}$ depending on altitude. Overall, the entire stream network of Badulu Oya illustrates dendritic drainage pattern. Greater extent of the catchment is occupied by tea plantations and paddy lands while hill stream area is heavily used to cultivate vegetables like seasonal crops where riverine areas are fully occupied by these cultivations. Badulu Oya covers a few main urban areas through its course to the confluence, especially the middle part of the river being densely populated.

Study was conducted during the period from July 2017 to February 2019 sampling surface water in selected locations all over the catchment in every other month. Sampling locations were selected based on elevation from 1,185 $\mathrm{m}$ at the uppermost reach of the river to $100 \mathrm{~m}$ at the lowest point. The river was categorized into three segments as (a) the upstream (elevation $>700 \mathrm{~m}$ ), (b) midstream (elevation between $300 \mathrm{~m}$ and $700 \mathrm{~m}$ ) and (c) downstream (elevation < $300 \mathrm{~m}$ ) based on altitudinal variation. Ten water quality parameters were analyzed in 14 sampling locations along the main channel covering the whole length of the Badulu Oya during both wet and dry seasons (Fig. 1).

\subsection{Surface water sample collection and analysis}

Surface water temperature (SWT) $\left({ }^{\circ} \mathrm{C}\right)$, dissolved oxygen (DO) (mg/L) and pH were measured in-situ using portable DO and $\mathrm{pH}$ meters, respectively. Total dissolved solids (TDS) (ppm), electrical conductivity (EC) $(\mu \mathrm{S} / \mathrm{cm})$, were measured using Benchtop TDS and EC meters after transferring the samples to the laboratory. Turbidity (FTU), Sulphate (mg/L), Nitrate-N (mg/L) and total phosphate (mg/L) levels were measured using YSI 9500 DR Photometer after transferring the samples to the laboratory.

Digitized terrain and hydro layers were obtained from the Department of Survey, Sri Lanka. ArcGIS 10.4.1 software was used to map the Badulu Oya catchment and hand-held GPS was used to record the positions and elevations of the sampling locations. 
Data were analyzed using Minitab 17 software. MANOVA and General Linear Model (GLM) were performed to investigate the significant difference of analyzed water quality parameters among river segments and seasons. Descriptive statistics were calculated to illustrate the mean, minimum and maximum values of the water quality parameters among the river segments over two seasons. Graphs were generated by Minitab 17 software and MS Excel 2016.

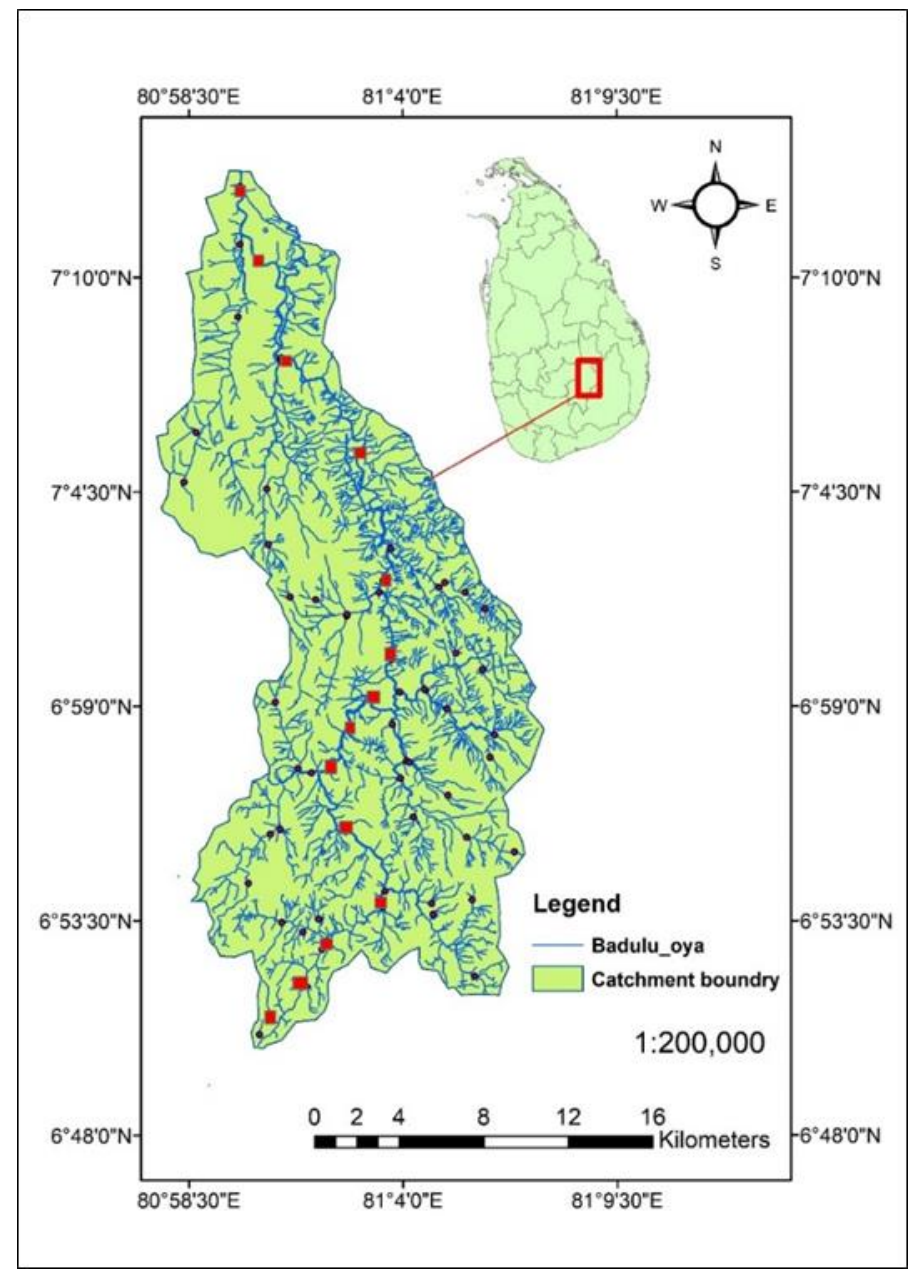

Figure 1 Map showing the Badulu Oya catchment area and sampling locations in the river

\section{Results}

\subsection{River elevation profile}

Elevation profile of the river with sampling locations along the main channel ranged from 1,185 m to $100 \mathrm{~m}$ (Fig. 2). Longest path of the river stretches for $59.9 \mathrm{~km}$ from its origin to the confluence with the river Mahaweli. Highest altitudinal tributaries draining to the main channel are Nawela Oya and Kuda Oya which occur around 2,000 m heights in Namunukula Hills. At the origin, streams of these tributaries form small waterfalls due to the high slope of the land and the solid bedrock. Cascades are common feature of these tributaries and flow rates are also high. Surface water temperature is also low due to high altitude. In the midstream segment (300 m-700 m) runs and ripples are common and higher number of tributaries join the main channel. This segment of the river is relatively flat. Lower segment $(<300$ $\mathrm{m}$ ) of the river is comparatively wider and shows flood plains and meanders. 


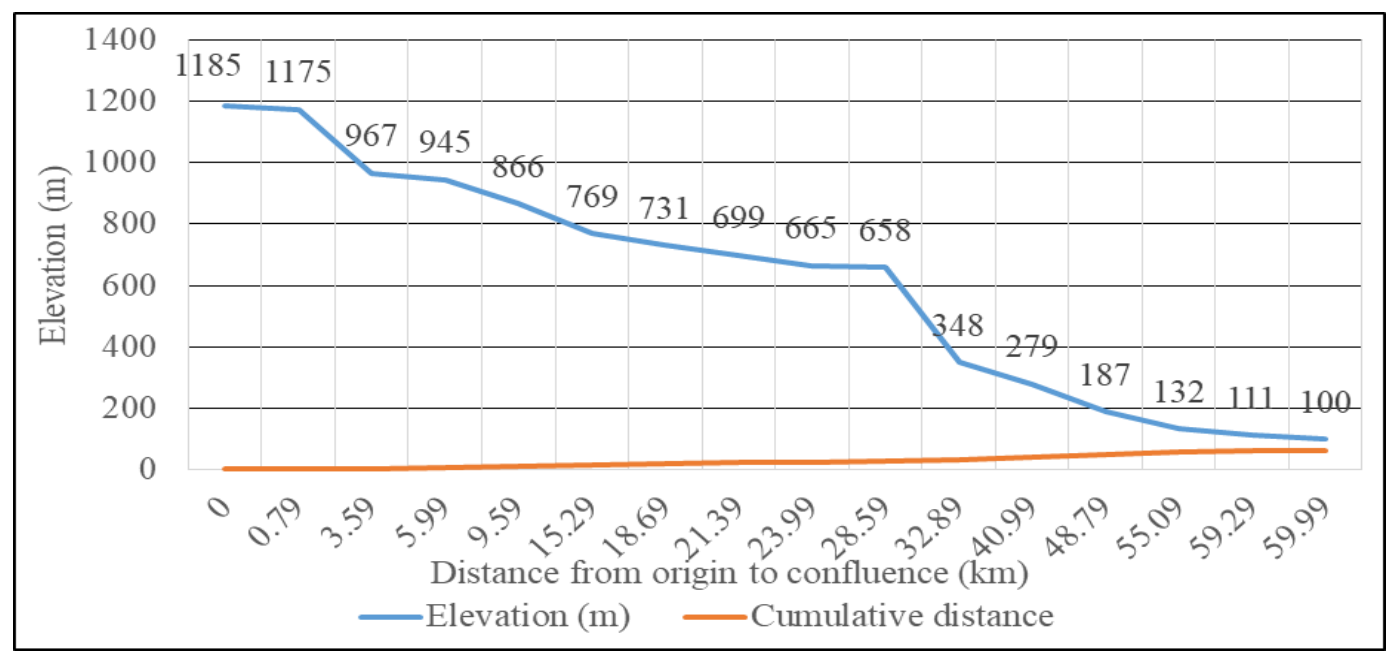

Figure 2 Elevation profile of Badulu Oya main channel including sampling point elevations

Highest elevation point in the catchment recorded as $2000 \mathrm{~m}$ and recorded lowest elevation was $100 \mathrm{~m}$ at the confluence. Total basin relief of Badulu Oya was $1,900 \mathrm{~m}$. Basin relief determines the slope and so the runoff and sediment transport within the catchment and finally along the main channel [9]. Relief ratio measures the overall steepness of the drainage basin and is an indicator of the intensity of erosion processes. Ruggedness number (Rn) for Badulu Oya was 5.6 that indicated a very high basin relief. Schumn, [10] explained that kind of high Rn values are characteristic to the mountainous region of tropical climate with high rainfall [9].

\subsection{Temporal variation of water quality}

SWT, DO and pH do not show any significant seasonal variation (Table 1). SWT range from $20.3^{\circ} \mathrm{C}$ to $29^{\circ} \mathrm{C}$ during both dry and wet seasons covered by the study period. DO levels range between 5.7 and $9.9 \mathrm{mg} / \mathrm{L}$ during the dry season and $4.8-10.2 \mathrm{mg} / \mathrm{L}$ during the wet season. $\mathrm{pH}$ range between 6.21 and 8.94 during the dry season while $6.8-8.7$ during the wet season.

EC, TDS, Turbidity, $\mathrm{SO}_{4}^{-2}, \mathrm{PO}_{4}^{-3}, \mathrm{NO}_{3}^{-}$and $\mathrm{BOD}$ values are significantly different between the two seasons (Table 1 ). Highest levels of EC and nitrate-N were recorded during the dry season $(1.08-4.8 \mathrm{mg} / \mathrm{L})$ and $0.88-4.64 \mathrm{mg} / \mathrm{L}$ during wet seasons. EC levels range between $81.5-558 \mu \mathrm{S} / \mathrm{cm}$ and $80.7-370 \mu \mathrm{S} / \mathrm{cm}$ during dry and wet seasons, respectively.

TDS, Turbidity and $\mathrm{SO}_{4}^{-2}$ levels are comparatively higher in wet season than in dry season. Higher $\mathrm{PO}_{4}{ }^{-3}$ levels $(0.13-$ $2.9 \mathrm{mg} / \mathrm{L}$ ) observe during both seasons without much variation. Similarly, same BOD ranges of $0.8-5.9 \mathrm{mg} / \mathrm{L}$ and 0.6 $5.9 \mathrm{mg} / \mathrm{L}$ were found during dry and wet seasons, respectively.

As reported by Gunawardhana [6], water quality parameters, namely, EC, Total Solids (TS), TDS, Total Suspended Solids (TSS), DO, alkalinity and $\mathrm{NO}_{3}-\mathrm{N}$ in Badulu Oya catchment are significantly influence by the seasonal impacts and the degree of catchment disturbances.

\subsection{Altitudinal variation of water quality}

Except for $\mathrm{pH}, \mathrm{PO}_{4}^{-3}, \mathrm{NO}_{3}{ }^{-}$and BOD, all other measured surface water quality parameters were significantly different among the three segments (Table 1). Downstream segment recorded highest mean temperature during the study period while lowest was recorded in the upstream segment.

Highest mean pH, DO, EC were recorded in downstream segment whereas upstream segment recorded the highest TDS levels. At the same time, midstream segment recorded highest mean turbidity, $\mathrm{SO}_{4}{ }^{-2}, \mathrm{PO}_{4}^{-3}$ levels. Mid and downstream segments both had same mean $\mathrm{NO}_{3}$ - levels. 
Table 1 Segment wise and seasonal wise variations of measured water quality parameters

\begin{tabular}{|c|c|c|c|c|c|c|c|c|c|c|}
\hline \multirow{2}{*}{ Parameter } & & \multicolumn{4}{|c|}{ River Segment } & \multicolumn{3}{|l|}{ Season } & \multicolumn{2}{|c|}{$\begin{array}{l}\text { CEA } \\
\text { standards }\end{array}$} \\
\hline & & $\begin{array}{l}\text { Up } \\
\text { stream }\end{array}$ & $\begin{array}{l}\text { Mid } \\
\text { stream }\end{array}$ & $\begin{array}{l}\text { Down } \\
\text { stream }\end{array}$ & $\begin{array}{l}\text { p- } \\
\text { value }\end{array}$ & Dry & Wet & $\begin{array}{l}\text { p- } \\
\text { value }\end{array}$ & $\mathbf{A}$ & B \\
\hline \multirow{2}{*}{$\begin{array}{l}\text { Temperature } \\
\left({ }^{\circ} \mathrm{C}\right)\end{array}$} & Mean & 23.55 & 24.08 & 26.34 & 0.00 & 24.81 & 24.50 & 0.32 & & \\
\hline & SE & 0.23 & 0.28 & 0.28 & & 0.23 & 0.20 & & - & - \\
\hline \multirow[t]{2}{*}{ DO (mg/L) } & Mean & 7.78 & 8.20 & 8.60 & 0.00 & 8.33 & 8.06 & 0.11 & 6.00 & 5.00 \\
\hline & SE & 0.13 & 0.16 & 0.16 & & 0.13 & 0.11 & & & \\
\hline \multirow[t]{2}{*}{$\mathrm{pH}$} & Mean & 7.54 & 7.64 & 7.76 & 0.23 & 7.67 & 7.62 & 0.59 & $6-8.5$ & $6-9$ \\
\hline & SE & 0.08 & 0.10 & 0.10 & & 0.08 & 0.07 & & & \\
\hline \multirow[t]{2}{*}{$\mathrm{EC}(\mu \mathrm{S} / \mathrm{cm})$} & Mean & 255.60 & 232.10 & 282.70 & 0.00 & 281.70 & 231.80 & 0.04 & - & - \\
\hline & SE & 11.40 & 13.90 & 13.90 & & 11.20 & 10.10 & & & \\
\hline \multirow[t]{2}{*}{ TDS (ppm) } & Mean & 156.03 & 117.70 & 132.90 & 0.03 & 156.15 & 114.90 & 0.00 & - & - \\
\hline & SE & 9.13 & 11.20 & 11.20 & & 9.01 & 8.08 & & & \\
\hline \multirow{2}{*}{$\begin{array}{l}\text { Turbidity } \\
\text { (FTU) }\end{array}$} & Mean & 5.65 & 7.97 & 3.97 & 0.03 & 3.39 & 8.35 & 0.00 & 5.00 & - \\
\hline & $\mathrm{SE}$ & 0.86 & 1.05 & 1.05 & & 0.85 & 0.76 & & & \\
\hline \multirow{2}{*}{$\begin{array}{l}\mathrm{SO}_{4}^{-2} \\
(\mathrm{mg} / \mathrm{L})\end{array}$} & Mean & 8.50 & 9.95 & 6.42 & 0.01 & 6.31 & 10.27 & 0.00 & 250.00 & - \\
\hline & $\mathrm{SE}$ & 0.65 & 0.80 & 0.80 & & 0.65 & 0.58 & & & \\
\hline \multirow{2}{*}{$\begin{array}{l}\mathrm{PO}_{4}^{-3} \\
(\mathrm{mg} / \mathrm{L})\end{array}$} & Mean & 0.61 & 0.74 & 0.61 & 0.36 & 0.74 & 0.56 & 0.03 & 0.70 & 0.70 \\
\hline & $\mathrm{SE}$ & 0.06 & 0.08 & 0.08 & & 0.06 & 0.06 & & & \\
\hline \multirow{2}{*}{$\begin{array}{l}\mathrm{NO}_{3}^{-} \\
(\mathrm{mg} / \mathrm{L})\end{array}$} & Mean & 0.12 & 0.15 & 0.15 & 0.22 & 0.12 & 0.11 & 0.00 & 10.00 & 10.00 \\
\hline & SE & 0.02 & 0.03 & 0.03 & & 0.02 & 0.02 & & & \\
\hline \multirow{2}{*}{$\begin{array}{l}\text { BOD } \\
(\mathrm{mg} / \mathrm{L})\end{array}$} & Mean & 2.47 & 2.81 & 2.32 & 0.18 & 3.05 & 2.01 & 0.00 & 3.00 & 4.00 \\
\hline & SE & 0.16 & 0.19 & 0.19 & & 0.16 & 0.14 & & & \\
\hline
\end{tabular}

\subsection{Comparison of water quality parameters with water quality standards}

Central Environmental Authority (CEA) of Sri Lanka has proposed ambient water quality standards under six categories. Out of them, two categories viz; Category A and B that water source for simple treatment and bathing and contact recreation respectively were used to compare with results of present study. Based on those standards pH and DO ranged within the proposed standard limits. Recorded turbidity levels exceeded the standard limits during wet season specially in midstream segment. During dry season in the midstream segment phosphate levels exceeded the standard limits. Elevated $\mathrm{PO}_{4}^{-3}$ levels above ambient water quality standards for aquatic life and irrigation purposes were also reported in the Badulu Oya catchment during the study conducted by Gunawardhana [11]. Irrespective of the segment, recorded BOD levels during the dry season exceeded the standard ambient water quality limits (Fig. 3). 
Rajapaksha et al. / GSC Biological and Pharmaceutical Sciences, 2020, 11(03), 226-234

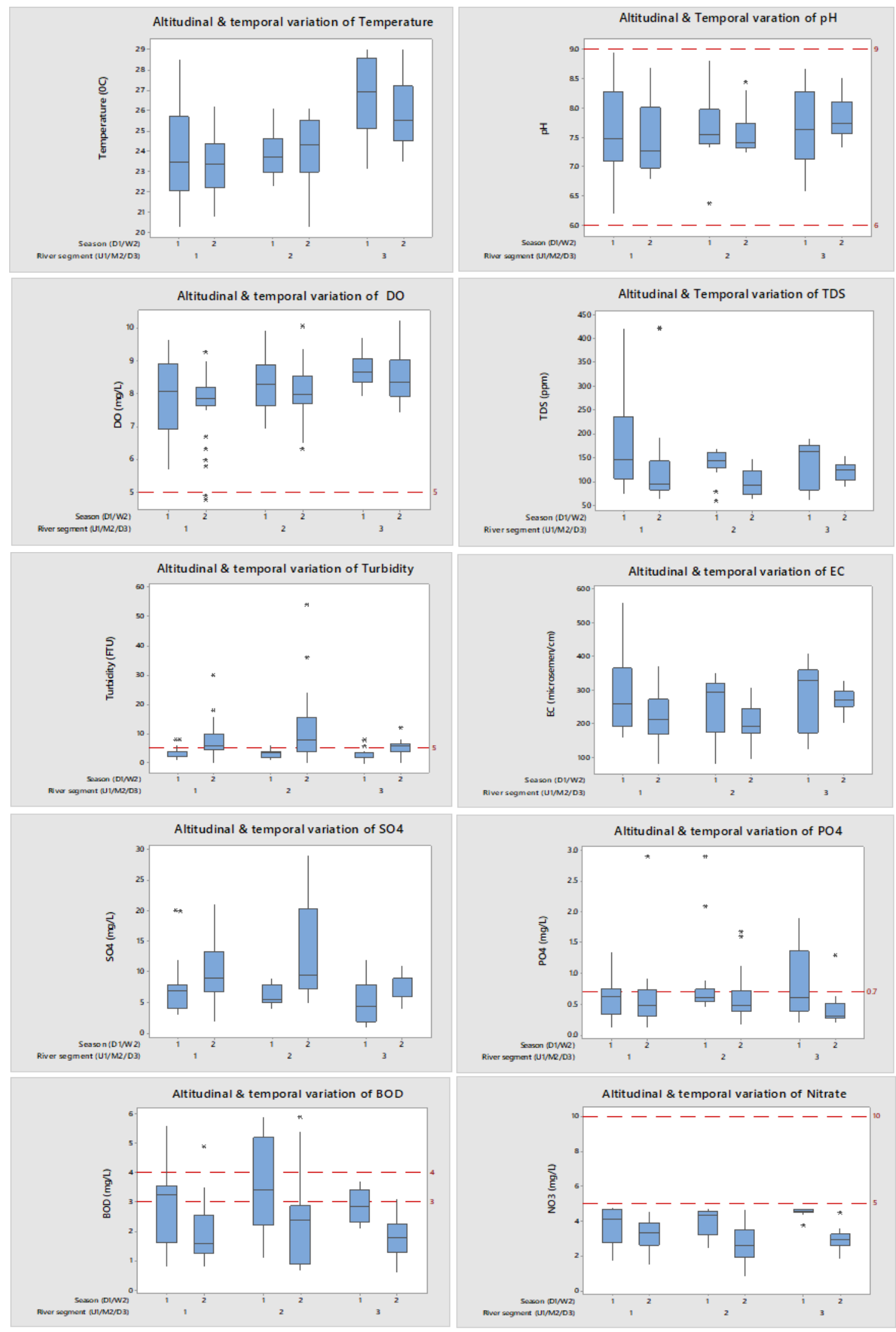

Figure 3 Graphical illustration of altitudinal and temporal variation of water quality parameters 


\section{Discussion}

Surface water quality varies according to altitude, climate, geomorphology, land use patterns and anthropogenic factors [12]. Climate in a particular region plays an important role in maintaining their hydrological process and especially chemical composition of surface water [13]. Available dominant rock types, crystallization process are the main factors that regulate the chemical composition and physical properties of surface water [14]. Badulu Oya catchment being located in the intermediate zone on the leeward side of Central Highlands receives an average $2000 \mathrm{~mm}$ comparatively low rainfall [15]. The catchment receives high rainfall during October to November and December to February second inter monsoon and during North East monsoon periods. During the rainy season, catchment receives $900-2500 \mathrm{~mm}$ of rainfall. Rest of the year is relatively dry and it receives only a low rain fall. May to September are the driest period of the catchment.

Based on the rainfall and runoff, quality of the water flow in Badulu Oya varies due to addition of chemical compounds through the runoff and dilution effects [16]. During rainy season most of the bare lands and disturbed soils due to short term cultivations erode and are washed into the stream [16] making stream water turbid elevating its TDS and EC levels [16]. On the other hand, agrochemicals applied in cultivations also drain into stream water increasing sulphate and nitrate levels in the stream water $[16,17]$. Land use of the upper catchment of the Badulu Oya is dominated by cultivated lands. Therefore, there is a high tendency of draining the applied fertilizers into the stream water. As reported by Bandara [18] and Gunawardhana [11] the fertilizer addition and nutrient pollution in the Badulu Oya catchment is high. Further, study conducted by Tong and Chen [19] found that increment in agricultural land had a strong positive correlation with conductivity and pH. During dry season, chemical parameter concentrations of the surface water goes up due to high evaporation rates and low discharges from the tributary streams.

Further, water temperature has significant effect on lotic ecosystem and its chemical properties [13]. The amount of dissolved oxygen in stream depends on the water temperature and these two are inversely related $[16,20]$. Moreover, biological and chemical degradation of compounds under oxidation processes and release of pollutants to the existing water and degradation of some pollutants from the existing water also depend on available temperature and DO conditions [21]. Available organic matter contents in river water due to urban or domestic waste discharge are also reduce the available DO levels since oxidation of the organic matter consume the DO in water [22]. Abundant home gardens and cultivation lands adjacent to river reservations cause leaching of fertilizer residues including high rates of $\mathrm{NO}_{3}-\mathrm{N}, \mathrm{PO}_{4}^{-3}$ and $\mathrm{SO}_{4}^{-2}$ values records in the stream water $[16,17,22]$.

Along the altitudinal gradient, upstream segments possess low temperatures and high DO levels. Due to fast flow rates, most of the added compounds flow downstream leading to concentrate and raise their concentrations in areas where water logging is common. It was evident that the concentration of $\mathrm{NO}_{3}$ - increased with distance from upstream to downstream [23]. Especially midstream segment shows the potential to accumulate urban waste. Agricultural discharges from upstream area also tend to get accumulated in this segment. The concentration of pollutant compounds further exacerbates with addition of excessive urban discharges where comparatively dense human populations are occurred in urban areas influence more on water quality degradation [24]. It is evident that the values of resulted water qualities in midstream area indicate the influence of point sources as well as non-point sources pollution that is commonly associated with urbanized areas [25]. Flow rates and turbulent flows due to boulders and cobbles in the river bed allow continuous aerations supporting to self-purification capacity of river and natural degradation of pollutants [21]. Under good sunlight some chemicals photo degrades and microbes and macro invertebrates also support to bio degradation of the pollutants. Considerably rich riparian vegetation in the catchment, especially remote and forested areas, support phytoremediation too. As occurs in "Thaulla" a part of tank cascade system that removes nutrients, sediments and heavy metals [26] river flows reaching downstream segments are comparatively low in pollutant additions due to the area is remote low populated area and river flow pass riverine forested areas as well have a high dilution effect due to water discharges from the tributaries.

Although pristine forest covers are limited some reforested mountains are present in the catchment. In high altitudes, most of the catchment is covered by tea plantations while mid and downstream segments adjacent to river lands are occupied by short-term cultivations, vegetable and paddy. Vegetable plots are common and prominent land use type in the upstream segment. The Midstream segment receives high load of urban and residential waste discharges mainly from populated urban areas where three main towns are located adjacent to the river banks. Leachate of the municipal waste dump site also reach the main stream at midstream segment. Encroachment of river reservations for residential and cultivation purposes especially in midstream segment and the slow flow velocity reduce the ability of effective water aeration and hence self-purification. Further, as per Silva, [14] out of many factors that influence to water quality of surface waters, more prominent effects are related to irrigative agriculture practices, catchment land use and 
unplanned human settlements in highly urbanized areas. These are common for the surface water quality deterioration in Badulu Oya catchment too.

\section{Conclusion}

Results revealed that the observed water quality parameters are significantly vary $(<0.05)$ both seasonally and altitudinally. Although turbidity, phosphate, and BOD levels exceed the Sri Lankan ambient water quality standards, the overall water quality in some segments and some seasons is still at safe levels probably due to natural purification. Since the Badulu Oya is the main drinking and domestic water source of the majority of urban and rural communities, in the area, maintaining the stream health is vital for the health of the consumers as well as survival of the aquatic life in the catchment.

\section{Compliance with ethical standards}

\section{Acknowledgments}

The authors gratefully acknowledge financial support given to this research from the University Grants Commission, Sri Lanka.

\section{Disclosure of conflict of interest}

Rajapaksha R.M.G.N., ${ }^{*}$ Dharmagunawardhane H.A., Attanayake A.M.A.N.B., Rekha Nianthi K.W.G. declare that they have no conflict of interest.

\section{References}

[1] Margalef R. (1994). The place of epicontinental waters in global ecology. In: R Margalef (ed.) Limnology Now: A Paradigm of Planetary Problems. Elsevier Science B.V, 1-8.

[2] Muller B, Lotter AF, Sturm M and Ammann A. (1998). Influence of catchment quality and altitude on the water and sediment composition of 68 small lakes in Central Europe. Aquat.sci, 60, 316-337.

[3] Jackson A. (2014). Long \& Cross Profiles Geography as notes.

[4] Death RG and Winterbourn MJ. (1995). Diversity patterns in stream benthic invertebrate communities: The influence of habitat stability. Ecology, 76, 1446 - 1460.

[5] Atukorala, AKDN. (2012). Diversion of Excess Water in Badulu Oya for Augmentation of Loggal Oya Reservoir for Generation of Hydropower (Concept Paper). ENGINEER - 45(03), 45 - 48.

[6] Gunawardhana WDTM, Jayawardhana JMCK, Udayakumara EPN and Malavipathirana S. (2018). Spatio-temporal variation of water quality and bio indicators of the Badulu Oya in Sri Lanka due to catchment disturbances. J.Natn.Sci.Foundation. Sri Lanka, 46(1), 51-67.

[7] Ranasinghe PN, Fernando GWAR, Dissanayake CB, Rupasinghe MS and Witter DL. (2009). Statistical evaluation of stream sediment geochemistry in interpreting the river catchment of high-grade metamorphic terrains. Journal of Geochemical Exploration, 103, 97-114.

[8] Sanjeewa WGC, Mendis ASM, Wijekoon WBMMW and Liyanage R. (2015). Trend Analysis in Rainfall \& Runoff Regime and Land Use Cover Change in Badulu Oya Upper Catchment. Annual Sessions of IESL, The Institution of Engineers, Sri Lanka, 381 - 385.

[9] Babu KJ, Sreekumar S and Aslam A. (2016). Implication of drainage basin parameters of a tropical river basin of South India. Appl Water Sci, 6, 67-75.

[10] Schumn SA. (1956). Evolution of drainage system and slopes in badlands at Perth Amboy, New Jersey. Geol Soc Am Bull, 67, 597-646.

[11] Gunawardhana WDTM Jayawardhana JMCK and Udayakumara EPN. (2016). Impact of agricultural practices on water quality in Badulu Oya catchment area in Sri Lanka. Ileperuma OA, Priyantha N, Yatigammana SK and Wijesundara C. (eds.) (2016): Symposium Proceedings, Fifth International Symposium on Water Quality and Human Health: Challenges Ahead, PGIS, Peradeniya, Sri Lanka, 2. 
[12] Bi R, Chen X, Zhang J, Ishizaka J, Zhuang Y, Jin H, Zhang H and Zhao M. (2018). Water Mass Control on Phytoplankton Spatiotemporal Variations in the Northeastern East China Sea and the Western Tsushima Strait Revealed by Lipid Biomarkers. Journal of Geophysical Research Bio geosciences, 123(4), 1318-1332.

[13] Whitehead PG, Wilby RL, Battarbee RW, Kernan M and Wade AJ. (2009). A review of the potential impacts of climate change on surface water quality. Hydrological Sciences Journal, 54(1), 101-123.

[14] Silva EIA. (1996). Water quality of Sri Lanka. a review on twelve water bodies. Department of Environmental Sciences. Institute of Fundamental Studies. Kandy, Sri Lanka, 1-30.

[15] Perera ENC, Jayawardana DT and Jayasinghe P. (2017). A Rainfall Intensity-Duration Threshold for Mass Movement in Badulla, Sri Lanka. Journal of Geoscience and Environment Protection, 5, 135-152.

[16] Shrestha S and Kazama F. (2007). Assessment of surface water quality using multivariate statistical techniques; A case study of the Fuji river basin, Japan. Environ. Model. Software, 22, 464-475.

[17] Akubugwo EI, Nwachukwu MI, Odika PC and Duru MKC. (2013). Water quality assessment of Njaba River,Nigeria. Journalof Environmental Science, Toxicology and Food Technology, 4(6), 33-37.

[18] Bandara JM, Wijewardena HV, Bandara YM, Jayasooriya RG and Rajapaksha H. (2011). Pollution of River Mahaweli and farmlands under irrigation by Cadmium from agricultural inputs leading to a chronic renal failure epidemic among farmers in NCP, Sri Lanka. Environ Geochem Health, 33(5), 439-445.

[19] Tong STY and Chen W. (2002). Modeling the Relationship between Land Use and Surface Water Quality. Journal of Environmental Management, 66(4), 377-393.

[20] Wetzel RG. (2001). Limnology Lake and River Ecosystems. Third Edition, Academic Press, San Diego, 1006.

[21] Bu H, Tan X, Li S and Zhang Q. (2010). Temporal and spatial variations of water quality in the Jinshui River of the South Qinling Mts., China. Ecotoxicol. Environ. Saf.

[22] Kannel PR, Lee S and Lee YS. (2008). Assessment of spatial-temporal patterns of surface and ground water qualities and factors influencing management strategy of groundwater system in an urban river corridor of Nepal. J. Environ. Manage, 86, 595-604.

[23] Wijayawardhana RGA, Zoiza AKN and Dharmagunawardhane HA. (2004). Effect of fertilizer application in upcountry tea lands on Downstream pollution (Abstr.) Proceedings of the Annual Research Sessions, University of Peradeniya, Sri Lanka, 9, 192.

[24] Kazi TG, Arain MB, Jamali MK, Jalbani N, Afridi HI, Sarfraz RA, Baig JA and Shah AQ. (2009). Assessment of water quality of polluted lake using multivariate statistical techniques: a case study. Ecotoxicol. Environ. Saf. 72, 301309.

[25] Sliva L and Williams DD. (2001). Buffer zone versus whole catchment approaches to studying land use impact on river water quality. Water Research, 35(14), 3462-3472.

[26] Mahatantila K, Chandrajit R, Jayasena HAH and Ranawana KB. (2008). Spatial and temporal changes of hydrogeochemistry in ancient tank cascade systems in Sri Lanka: evidence for a constructed wetland. Water and Environment Journa,1 22, 17-24.

\section{How to cite this article}

Rajapaksha RMGN, Dharmagunawardhane HA, Attanayake AMANB and Rekha Nianthi KWG. (2020). Altitudinal and temporal variation of surface water quality: An assessment in Badulu Oya Catchment, Sri Lanka. GSC Biological and Pharmaceutical Sciences, 11(3), 226-234. 